\title{
"And They Read in That Night Books of History": Consuming, Discussing, and Producing Texts about the Past in al-Ghawrī's Majālis as Social Practices
}

\author{
Christian Mauder
}

\begin{abstract}
[Al-Walīd b. Yazīd] once grabbed his brother and fornicated with him. Moreover, he wanted to drink [wine] on top of the Kaba. The author of the work of history (șâhib al-tārīkh) said: "No one from among the Muslims did ('amila) what al-Walīd did." Bon mot (durra): He whose victory may be glorious [i.e., Sultan al-Ghawrī] said: "Nay, neither a Christian nor a Mazdaist nor any other person who ever did anything (ahad min al-āmilīn) did something similar to what this ill-fated sinner (al-fājir almanḥuss) did."
\end{abstract}

This passage comes from one of the three surviving accounts of the majālis, or learned gatherings, that the penultimate Mamluk sultan Qānișawh al-Ghawrī (r. 9o6-22/1501-16) convened at the Cairo Citadel. More precisely, the passage forms part of a section depicting how al-Ghawrī and members of his court ${ }^{2}$

* This chapter is based on research results from my dissertation In the sultan's salon: Learning, religion and rulership at the Mamluk court of Qānișawh al-Ghawrī (r. 1501-1516), which I defended at the University of Göttingen in 2017 and am currently preparing for full publication; cf. esp. chapters 3.1.1, 3.1.5., 4.1.1., 4.2, 4.2.7, and 6.3.1. The writing of this chapter was supported by the Humanities Research Fellowship Program of New York University Abu Dhabi and by the Institute for Advanced Study, Princeton, NJ. I would like to thank the participants of the Fifth Conference of the School of Mamluk Studies in general and Konrad Hirschler, Gowaart Van Den Bossche, and Jo Van Steenbergen in particular for their helpful feedback on an earlier version of this chapter. Furthermore, I am obliged to the Directorates of the Süleymaniye Kütüphanesi, Istanbul, and the Topkapı Sarayı Kütüphanesi, Istanbul, for granting me access to the analyzed manuscripts.

1 Anonymous, al-'Uqūd i, fol. $83^{\mathrm{r}}$.

2 For the purposes of the present chapter, I understand "courts" as internally stratified social bodies centered around the person of a ruler and distinguished by regular access to him or her. For a more refined discussion of what constitutes a court, see Mauder, Salon, chapters $1.2 .1-1.2 .4$. 
engaged with Umayyad history in general and with the reign of Caliph Walid b. Yazīd (r. 125-6/743-4) in particular. In many ways, the quote is typical of how members of al-Ghawri’s court approached historical topics. First, the passage clearly shows that information about the past was taken from written historiographical texts, although — and this is likewise typical—the surviving accounts do not identify these works by title. Second, historical knowledge was not only consumed but also interpreted, developed, and produced by commenting on and adding to the available historical literature. Third, in the majālis accounts, the members of the late Mamluk court appear as making implicit or explicit statements about themselves. In the passage quoted, for example, Sultan al-Ghawrī condemns the actions of an almost proverbially wicked ruler, thus claiming for himself a rank of moral superiority.

The accounts of al-Ghawrīs majälis provide deep insight into the dynamics of the consumption, performative presentation, and production of texts about the past at the Mamluk court, that is, the court of the rulers of the Islamicate polity known in European languages as the Mamluk Sultanate that was in its political, social, religious, cultural, and linguistic characteristics significantly shaped by the fact that many members of its political elite, including numerous rulers, were former military slaves (mamlüks). Moreover, the accounts indicate that members of the sultan's court invested considerable time, effort, and cultural capital into engaging with historiographical material. In what follows, I argue that this engagement was part of a dense web of social practices ${ }^{3}$ that served multiple purposes, including, but not limited to, the representation and legitimation of al-Ghawrìs rule, the exchange and acquisition of cultural capital, the performative enactment and reaffirmation of the courtiers' membership in a refined elite of $u d a b \bar{a}^{3}$, i.e., persons possessing $a d a b,{ }^{4}$ the social construction of a shared reality, ${ }^{5}$ the commemoration of events central to the identity of members of the court, and the enjoyment of aesthetic pleasure.

My argumentation proceeds in five steps. The following section provides information on al-Ghawrì's majälis as courtly events and their historical background. Thereafter, I analyze practices of the consumption of historical texts

3 I follow Wedeen, Visions 15, in understanding social practices as "actions or deeds that are repeated over time; they are learned, reproduced, and subjected to risk through social interaction ... They tend to be intellegible to others in context-depending ways."

4 Classical studies of this multifaceted concept include Lichtenstädter, Conception; Nallino, Littérature, esp. 7-34. More recent are, e.g., Bonebakker, Adab; Fähndrich, Begriff; Gabrieli, Adab; Pellat, Adab; Lapidus, Knowledge (with a focus on its religious aspects); Bauer, Adab; Hämeen-Anttila, Adab; Enderwitz, Adab.

5 On the social construction of reality, see Berger and Luckmann, Construction. 
during these events. The subsequent section sheds light on practices of discussing and commenting on works about the past in the sultan's majälis. The following part scrutinizes the production of such works at the Mamluk court. The final section summarizes my main findings and discusses their broader implications for our understanding of late Mamluk intellectual history.

\section{$2 \quad$ Al-Ghawrī's Majālis in Historical Context}

Qānișawh al-Ghawrī ruled as Mamluk sultan over Egypt, Syria, and neighboring regions during a time when the Mamluk Sultanate faced multiple external and internal challenges, including the rise of the rivaling Muslim polities of the Ottomans and the Safavids, the sudden appearance of Portuguese sailors in the Indian Ocean and the Red Sea after their circumnavigation of Africa, consequent shifts in trade routes, recurring outbreaks of the plague, troop mutinies, and a long-lasting trend toward economic contraction. ${ }^{6}$ Moreover, al-Ghawrī had attained the sultanic throne only after a long and violent succession struggle in which half a dozen rulers rapidly succeeded each other over a period of less than five years-a development that demonstrated the contingency of the person of the Mamluk ruler. ${ }^{7}$ In this period of violent conflicts and pronounced economic hardship, al-Ghawrī relied on highly contested measures, such as uncanonical taxes, expropriations, forced purchases, and sales of offices, to collect the revenue necessary for the continued functioning of the sultanic administration, the upkeep of the military, the funding of major construction projects, and the alimentation of his court. ${ }^{8}$ Consequently, chroniclers of the period decried the sultan as a particularly unjust ruler whose fiscal schemes stood in opposition to established practices of good governance. ${ }^{9}$

In spite of and, as it seems, in reaction to these phenomena of crisis, the sultan maintained a lavish court life that included hosting regular majälis, which primarily took place in various halls of the Cairo Citadel during the evenings of two to three days per week. The courtly attendees of these events included high-ranking members of the scholarly and administrative elite such as current and former chief judges, the sultan's private secretaries, and holders of teaching positions in prominent madrasas of Cairo. Further participants encompassed

6 On the challenges that Mamluk rulers of al-Ghawrīs generation faced, see Petry, Twilight; Protectors; Elbendary, Crowds, esp. 104; Mauder, Salon, chapter 6.1.

7 See Mauder, Herrschaftsbegründung.

8 See Petry, Protectors; Twilight; Institution; Paradox.

9 See Mauder, Salon, chapters 2.1.1-2.1.2.3. 
traveling scholars, poets, diplomats, and foreign dignitaries, among whom the Ottoman prince Abū l-Khayr Muhammad Qorqud (d. 918/1513), the son of Bāyezìd II (r. 886-918/1481-1512), stands out as the highest ranking. While the majālis sported less prominent participants, such as musicians and servants, apart from Sultan al-Ghawrī, members of the military elite were conspicuously absent. This last observation highlights the decidedly civilian and largely scholarly character of the gatherings. ${ }^{10}$

Most of what we know about these events comes from three sources claiming to provide eyewitness accounts of the gatherings, all of which are preserved in unique manuscripts originally produced for al-Ghawrìs palace library and located today in Istanbul. While two of them, al-Kawkab al-durri fi masāill al-Ghawrī (The brilliant star on al-Ghawrì's questions) $)^{11}$ and al- 'Uqüd al-jawhariyya fi l-nawādir al-Ghawriyya (The jewel necklaces on al-Ghawri's anecdotes), ${ }^{12}$ provide very little information on their background and authorship, the third one, Nafä̀is majālis al-sulțāniyya fì haqā̄ì asrār al-Qurāniyya (sic, The gems of the sultanic gatherings on the truths of Quranic mysteries), can be safely attributed to one of the sultan's clients by the name of Husayn $b$. Muhammad al-Ḥusaynī(fl. 911/1506), known as al-Sharīf. ${ }^{13}$ Unlike al-Kawkabaldurrī and al- Uqüd al-jawhariyya, which claim to contain "best of" collections of the proceedings of majālis taking place during multiyear periods, al-Sharif provides detailed accounts of 96 gatherings that took place between Ramaḍān 910 (beginning in February 1505) and Sha'bān 911 (beginning in December $1505) \cdot{ }^{14}$

10 Mauder, Salon, chapters 4.1-4.1.2.4.

11 MS Istanbul, Topkapı Sarayı Kütüphanesi, Ahmet III 1377. The text was partly edited in 'Azzām (ed.), Majālis. Hereafter, references to the manuscript are preceded by (MS) and use the pagination in the manuscript. Page numbers in the edition are indicated by (ed. 'Azzām). All quotations for which references to both the edition and the manuscript are given are based on the manuscript.

12 MS Istanbul, Süleymaniye Kütüphanesi, Ayasofya 3312 and 3313. On this text, see also Mauder and Markiewicz, Source.

13 MS Istanbul, Topkapı Sarayı Kütüphanesi, Ahmet III 268o. The text was partly edited in 'Azzām (ed.), Majālis. Hereafter, references to the manuscript are preceded by (Ms) and use the pagination in the manuscript. Page numbers in the edition are indicated by (ed. 'Azzām). All quotations for which references to both the edition and the manuscript are given are based on the manuscript.

14 On these texts, see, in addition to Mauder, Salon; also Awad, Sultan; Behrens-Abouseif, Arts; Berkey, Mamluks; Conermann, Es boomt 50-1; Flemming, Activities; Perser; Nachtgesprächen; Frenkel, Culture 11; Nations 63, 68-9; Irwin, Thinking; Literature 28; Mauder and Markiewicz, Source. 
The three sources indicate that the majālis attendees (including the sultan) discussed during their meetings scholarly questions from a broad array of different disciplines. The fact that Nafäis majälis al-sulțāniyya claims to provide a holistic description of the gatherings during a limited period allows us to make quantitative estimates about the frequency with which questions from various fields of learning came up in the gatherings. According to the data provided in this source, legal questions clearly predominated and constituted about a third of the topics of the majālis, followed by issues of Quranic exegesis, which accounted for about a fifth of the debates. About an eighth of the debates focused on poetry, rhymed riddles, anecdotes, and other forms of literature, the remainder of the debated questions coming largely from the fields of rational theology, stories about the prophets before Muhammad, history, and prophetic traditions, all of which appear to have been of roughly the same level of prominence and accounting each for slightly less than ten percent of the discussed material. History or tārikkh, as it is called in the accounts of the majālis, was thus a recurrent and regular, albeit not the most frequent, discussion topic among the scholars, officials, and foreign visitors that the sultan brought together.

\section{Consuming Texts about the Past}

Unlike most other fields of learning in which the majālis apparently relied mostly on memorized material and rational argumentation, written texts figured prominently in scholarly exchanges about historical topics. The accounts of al-Ghawrìs majälis indicate that copies of works about the past were physically present during these events and read aloud for the consumption of members of the court. In addition to the quotation given at the very beginning of this chapter, al-Kawkab al-durrī refers, for example, to Abū Ḥayyān al-Tawhīdī's (d. ca. 414/1023) anthology al-Bașä̉ir wa-l-Dhakhāir (Insights and treasures) as a source of historical knowledge about the companions of the Prophet Muhammad..$^{15}$ Such a clear identification of a work by title and author is rather untypical, given that al-'Uqüd al-jawhariyya and Nafäis majālis al-sulțanniyya often use rather vague phrases such as "they read in the book of history (qara'ü fi l-tārïkh),"'16 "it was mentioned in the book of history (dhukira fi l-tärīkh),"17 "the author of the book of history said (qāla șāhib al-

\footnotetext{
15 Anonymous, al-Kawkab (Ms) 77; (ed. 'Azzām) 53.

16 Al-Sharīf, Nafä̀is (Ms) 213.

17 Ibid. 219.
} 
tärïkh),"18 or "and they read in that night books of history (wa-qara'ü fi tilka l-lalya al-tawārīkh)." ${ }^{\prime 19}$

In several cases, it is possible to trace back historical material that the sources attribute in such a vague manner to Ahmad b. Muhammad Ibn Khallikān's (d. 681/1282) famous biographical dictionary Wafayāt al-a'yān waanba $\vec{a}^{3}$ abna $\vec{a}^{3}$ al-zamān (The [reports] about the deaths of famous persons and the news on the children of time), which seems to have been one of the most frequently studied historiographical works in the majälis. ${ }^{20}$ Among other things, the participants at the sultan's gatherings read in this work about the lives of prominent early Muslims such as the caliphs 'Uthmān b. 'Affān (d. 35/656) ${ }^{21}$ and 'Alī b. Abī Taalib (d. 40/661), ${ }^{22}$ important rulers, including the Umayyad Sulaymān b. 'Abd al-Malik (d. 99/717), ${ }^{23}$ the 'Abbasid Abū Jaffar alManșūr (d. 158/775), ${ }^{24}$ and the Buyid 'Imād al-Dawla (d. 338/949), ${ }^{25}$ and famous figures of Islamicate learning, such as the linguist Yahyā b. Ya'mar (d. 129/746), ${ }^{26}$ the grammarian 'Alī b. Hamza al-Kisầì (d. 189/8o5), ${ }^{27}$ the philosopher al-Fārābì (d. 339/950), ${ }^{28}$ and the polymath Ibn al-Jawzì (d. 597/1200). ${ }^{29}$

The choice of Wafayāt al-ayān as one of the majālis participants' favorite reading materials is significant. In 1973, Hartmut Fähndrich noted (it would appear independently from Ulrich Haarmann's writings about the "literarization" of Mamluk historiography) "that Ibn Khallikān's Wafayāt represents a certain literarization of the genre of 'biographical dictionary' in that for the presentation of a great part of the material the literarizing approach of adab is employed." ${ }^{30}$ As "a mixture of educational and entertaining material or

\footnotetext{
18 Anonymous, al- $U q \bar{u} d \mathrm{i}, 83^{\mathrm{r}}$.

19 Al-Sharīf, Nafā̄is (MS) 215, 251; (ed. 'Azzām) 128 (tawārīkh in second case without article).

20 My understanding of biographical works as a form of history writing is based on al-Qadi, History.

21 Anonymous, al-'Uqūd i, 61' ${ }^{\mathrm{r}}$, based on Ibn Khallikān, Wafayāt al-a'yānn vi, 174.

22 Anonymous, al-Uqūd i, 61' ${ }^{\mathrm{r}}$, based on Ibn Khallikān, Wafayāt al-a'yānn vi, 164.

23 Anonymous, al- $U q \bar{u} d$ i, $75^{\mathrm{v}}-6^{\mathrm{r}}$, based on Ibn Khallikān, Wafayāt al-a yā̄n ii, 421.

24 Anonymous, al-'Uqūd i, 86'v , based on Ibn Khallikān, Wafayāt al-a yyān iii, 152-3.

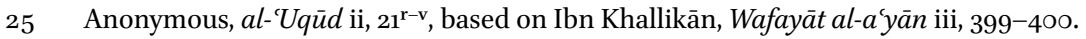

26 Anonymous, al-Kawkab (Ms) 115; Anonymous, al- Uqūd i, $73^{\mathrm{v}}{ }^{\mathrm{r}}{ }^{\mathrm{r}}$, based on Ibn Khallikān, Wafayāt al-a'yān vii, 218.

27 Anonymous, al-Kawkab (Ms) 112, based on Ibn Khallikān, Wafayāt al-áyān ii, 296.

28 Al-Sharīf, Nafāìs (MS) 251-2; (ed. 'Azzām) 128; Anonymous, al-'Uqūd ii, 22 ${ }^{\mathrm{v}-\mathrm{r}}$, based on Ibn Khallikān, Wafayāt al-a'yān v, 155-6.

29 Anonymous, al-Kawkab (MS) 279; Anonymous, al-'Uqūd ii, 23', based on Ibn Khallikān, Wafayāt al-a'yān iii, 141.

Fähndrich, Approach 440. See also Fähndrich, Man 30-3, 39.
} 
educational material presented as entertainment,"31 in Fähndrich's evaluation Wafayāt al-a'yān represents "a biographical dictionary with numerous features that are common to adab-works." ${ }^{2}$ While it would be oversimplistic to reduce the value of Wafayāt al-ayān to its entertaining and educational functions, we may assume that the members of al-Ghawrìs majālis selected this work for their practices of historiographic consumption - rather than any other of the dozens of available biographical dictionaries - precisely because of its literary qualities. Thanks to the latter, the collective reading of Wafayāt al-a'yann offered not only opportunities to acquire cultural capital but also to enjoy the aesthetic pleasures of a well-composed literary text.

Moreover, the members of al-Ghawri's court who met with the ruler in his majālis did not consume Ibn Khallikān's massive Wafayāt al-a'yān indiscriminately but rather focused on those parts of the work that were directly meaningful to their own social realities. A case in point is a passage from Ibn Khallikān concerning al-Fārābī and his patron, the Ḥamdanid ruler Sayf al-Dawla (r. 333-56/945-67), which both al-Uqūd al-jawhariyya and Nafäis majālis al-sulțāniyya mention as a topic of al-Ghawrìs majālis. The story addresses the question of the status of cultural capital vis-à-vis political power. In the version narrated in Nafä̀is majālis al-sulțāniyya, which clearly depends on the one in Wafayāt al-ay $\bar{a} n^{33}$ but paraphrases it to a considerable degree, it reads as follows:

Strange incident (gharība): It is said in the book of history (al-tārikh): Fārābī entered Sayf al-Dawla's majlis. The ruler said to him: "Sit down!" He asked: "Shall I sit down in my place (makān̄̄) or in your place?" [The ruler] said: "Sit down in your place." Thereupon, he sat down [in a place] above all [others] so that he dislodged Sayf al-Dawla from [his] throne (sarir).

Admonishing (ta'dīb): His Excellency, our lord the sultan [i.e., alGhawrī] said: "Al-Fārābī did not behave nicely (malīhan) [here], because he deemed it necessary to deal impolitely (qillatal-adab) with the shadow of God [on Earth]."

[The story continues:] Thereupon, Sayf al-Dawla's mamlüks wanted to kill al-Fārābī. They said to each other in Persian: "This man is impolite and feeble-minded (khafíf al-'aql)." Al-Fārābī said to them in Persian: "Be patient, for deeds should be judged according to their outcomes (innama

$31 \quad$ Fähndrich, Approach 437. See also Pauliny, Anekdote 143-4.

32 Fähndrich, Approach 437, see also 439-40; Begriff 340-1; Pauliny, Anekdote, esp. 146-56; Fähndrich, Man 28, 33-6, 211.

33 Ibn Khallikān, Wafayāt al-a'yān v, 155-6. 
l-a'māl bi-l-khawātim)!" Then, he debated with the scholars of the majlis and overcame them all. Sayf al-Dawla was amazed by his attitude and his awe-inspiring appearance (min hay'atihi wa-haybatihi) and said to him: “[Do you want to] eat a bite?” [Al-Fārābī] said: "No." [Sayf al-Dawla] asked: "[Do you want to] listen to a song (naghma)?" [Al-Fārābī] said: "Yes." [Sayf al-Dawla] thereupon had musicians brought in, but al-Fārābī did not like their performance and said: "If you would grant us permission, we would play a little." They said: "It is all right." Then, [al-Fārābī] took out a piece of wood, fastened strings on it and [began to] play. Thereupon, all people of the majlis laughed. Thereafter, he played [again] and they cried. Consequently, Sayf al-Dawla assigned him [a stipend of] two dīnārs per day. Al-Fārābī died in Syria. ${ }^{34}$

This passage was apparently of immediate interest to the members of alGhawrīs court for several reasons. First, the court of the famous Islamicate ruler Sayf al-Dawla was depicted as being remarkably similar to that of alGhawrī. Like the latter, in addition to the ruler, it encompassed scholars, musicians, and mamlüks who met to discuss scholarly topics in the sultan's majālis. The historical precedent of Sayf al-Dawla's court as portrayed by Ibn Khallikān thus allowed the members of al-Ghawrīs majälis to situate themselves in a shared tradition of Islamicate courtly culture dating back centuries and entailing a set of common cultural norms, expectations, and forms of expression. It provided the members of al-Ghawri's majālis with a point of reference for a shared social reality that transcended their immediate present through a historic precedent.

Second, the passage offered members of al-Ghawri's court an opportunity to engage more closely, and based on a concrete historical example, with one of the central concepts of this shared courtly reality, namely, adab. As the comment toward the beginning of the story attributed to al-Ghawri indicates, in the majälis, the term adab denoted primarily a combination of behavioral standards and a related body of knowledge members of courts were expected to master-and not, say, a certain type of literature. This understanding of $a d a b$ is also expressed elsewhere in the accounts of al-Ghawri’s majālis: Nafäis majālis al-sulțāniyya credits al-Ghawrī with the aphorisms ${ }^{35}$ "There is nothing in the world that is better than $a d a b$, for it adorns the rich and covers the poverty of

34 Al-Sharīf, Nafä̀is (MS) 251-2; (ed. 'Azzām) 128.

35 My understanding of the concept of aphorism in Arabic literature follows Berger, Aphorism. 
the poor" 36 and "There is nothing in the world that is better than adab. Adab is a jewel and the intellect ('aql) is its place of origin (lit. its mine)." "37 'Alī b. Abī Ṭālib is supposed to have stated, "A person's honor lies in his knowledge ('ilm) and his $a d a b$, and not in his origin (așl) and his lineage (nasab)."38 Moreover, among the majālis participants, not reacting properly to a fellow Muslim's greeting was considered an act of "neglecting (tark) [one's] adab,"39 whereas the correct choice of one's attire in a courtly context demonstrated one's good manners $(\bar{a} d \bar{a} b){ }^{40}$ The depiction of the members of al-Ghawrīs majālis as interested in such questions indicated that they themselves possessed $a d a b$ and were thus members of the cultural elite of $u d a b \bar{a}$. This status provided them with a shared identity not limited to members of the late Mamluk court but also encompassing past generations of learned and refined inhabitants of the Islamicate world with whom the members of al-Ghawri's court formed an imagined community, transcending their individual experiences and situating them in the broader context of Islamicate history. At the same time, their identity as $u d a b \bar{a}^{3}$ also legitimated the common exalted social position of members of the Mamluk court irrespective of their apparently quite diverse ancestry and origin, as the aphorism attributed to 'Alī b. Abī Țālib shows. We are thus dealing here with a shared identity based on moral and intellectual grounds, and not on ethnicity or kinship, as was arguably the case in most other Islamicate polities of the time, where membership in certain lineage groups was often a necessary, though not sufficient condition for elite status and access to courtly circles. Indeed, one may assume that to the minds of the participants in al-Ghawri's majālis, it was this emphasis on merit—and not ancestry — that set them apart from the courtly elites of other Islamicate polities of their time.

Third, the example of al-Fārābī's behavior in Sayf al-Dawla's majlis and his generous treatment by this ruler demonstrated not only the value of cultural capital and its transformability into economic benefits, thus presenting learning and the acquisition of knowledge as routes to worldly success, it also offered a role model and identification figure for the learned members of al-Ghawri's court, who could see themselves as standing in the tradition of the great philosopher. The fact that knowledge derived from the writings of scholars such as al-Fārābī, who built on the Greek philosophical heritage, was discussed and appreciated in al-Ghawrì's majälis makes this interpretation particularly plaus-

\footnotetext{
$36 \quad$ Al-Sharīf, Nafă’is (Ms) 6; (ed. 'Azzām) 4.

37 Al-Sharīf, Nafãis (Ms) 157; (ed. 'Azzām) 59.

38 Al-Sharīf, Nafẳis (Ms) 199; (ed. 'Azzām) 84.

39 Al-Sharîf, Nafä is (MS) 70.

40 Anonymous, al-Kawkab (Ms) 231.
} 
ible. ${ }^{41}$ Fourth, the story also offered a role model of proper rulership in the figure of Sayf al-Dawla, whom it presents as an ideal Muslim sovereign who reacted with forbearance to al-Fārābī's impolite behavior, demonstrated his support for learning and the arts by hosting majālis featuring both scholarly discussions and musical performances, and showcased his generosity by providing the philosopher with a generous stipend. To members of al-Ghawri's court, the similarities between Sayf al-Dawla and their sultan must have been evident, especially as far as the holding of majālis was concerned. The story thus established a connection between al-Ghawrī and a successful ruler of old, while also legitimating the Mamluk sultan as fulfilling the ethical expectations that could be deduced from the behavior of his famous predecessor.

Taken together, the example of the anecdote about al-Fārābì shows how important the consumption of written texts about the past could be for both al-Ghawri's court as a social body and its members, who through the collective reading of such texts interpreted, contextualized, negotiated, and justified their social status at the top of Mamluk society.

The members of al-Ghawri's majälis approached the textual tradition of historical knowledge not simply as passive recipients, but also by commenting on, debating, scrutinizing, and questioning its contents. The passage from al-'Uqüd al-jawhariyya quoted at the very beginning of this chapter is a case in point. It shows the sultan adding to the corpus of available historical knowledge by making an-in this case-negative comment about an earlier ruler who was widely regarded as one of the most amoral Muslim sovereigns of all times. Similarly, al-'Uqūd al-jawhariyya depicts al-Ghawrī also as adding his thoughts to a piece of historical information about another widely condemned ruler of old:

In the year 411[/1020-1], al-Hākim bi-Amr Allāh [The One Who Rules According To God's Decree], the ruler of the districts of Egypt, went missing when he was 36 years old. He had been a devil (shaytānn), of wicked disposition, fickle faith, and thirsting for bloodshed. He killed many people from among his officials in cold blood and was a heavy wine drinker ... Al-Ḥākim gave orders that nobody was to work during the day and that [everybody] was to stay awake at night instead of during the day. One day, 
he walked around and saw a tailor who was sewing while seated with a wax candle standing in front of him. Al-Hākim said to him: "Have you not heard of our ordinance?" He said: "Yes, oh commander of the faithful, but I have lighted the candle so that I can stay awake [in its light]." Thereupon, al-Hākim laughed about him and abolished [his ordinance].

Bon mot (durra): He whose victory may be glorious [i.e., al-Ghawrī] said: "It would have been fitting to call him al-Ḥākim bi-Ghayr Amr Allāh [The One Who Does Not Rule According To God's Decree] because God Most High created the day for earning one's livelihood and the night for what is to remain veiled." ${ }^{42}$

By commenting, in this passage and the one quoted at the beginning of this chapter, on the received historical knowledge about Walīd b. Yazīd and alḤākim bi-Amr Allāh and their qualities as notoriously bad rulers, al-Ghawrī made a statement about what it meant to be a good ruler, namely, governing in accordance with God's decrees, be it by following His commandments concerning proper behavior - contrary to Walīd b. Yazīd's example — or by respecting — unlike al-Hākim bi-Amr Allāh - the natural order of His creation. Moreover, by using Walīd b. Yazīd and al-Hākim bi-Amr Allāh as negative examples, the sultan also implicitly made a statement about his own rule: $\mathrm{He}$ knew how to govern in accordance with God's will and was, therefore, a legitimate sovereign.

Yet the historical material discussed in the majälis offered more than warnings about evil rulers. It also showed how virtuous Muslims of old exercised political authority. Again, the sultan is presented in our sources as engaging closely with this kind of material:

'Umar b. 'Abd al-'Azīz was strict toward his family and his relatives and took away from them much of what they possessed. Then they intrigued with his servant, poured poison for him [into a drink] and gave [the servant] one thousand dinārs. It is said that 'Umar knew that [poison] had been poured [into his drink]. He sent for his servant and said to him after he had treated him sternly: "What prompted you to pour [poison] for me [into my drink]?" He said: "They gave me one thousand dinārs for it and if I had continued to wait on you for one thousand years, I would not have made this [much money]." ['Umar] said to him: "Bring me [the money]."

42 Anonymous, al- $U q \bar{u} d \mathrm{ii}, 25^{\mathrm{r}-\mathrm{v}}$. I have not been able to pin down the source of this anecdote. 
[The servant] brought it to him and ['Umar] gave orders to put it in the treasury. He said to the servant: "Leave so that nobody sees you." The servant fled as he was told. 'Umar-may God have mercy on him-died in the year 101 $[/ 719-20]$. The duration of his reign was two and a half years. He lived for 39 years.

Bon mot (durra): He whose victory may be glorious [i.e., al-Ghawrī] said: "What is astonishing about him is that he abolished ... ${ }^{43}$ short period many wrongs (mazālim), among them the cursing of imām 'Alī-may God be pleased with him — and replaced it with the saying of Him Most High 'God decrees justice and good behavior.' Some of the earlier ones count him among the Rightly Guided Caliphs." ${ }^{44}$

Al- Uqüd al-jawhariyya portrays al-Ghawrī here as genuinely interested in the figure of the Umayyad Caliph 'Umar b. 'Abd al-'Aziz (r. 99-101/717-20), who appears in the quoted passage as a paragon of severity and justice toward his family, leniency toward his subjects, and pious respect toward the Prophet's family. Through his study of 'Umar's example, al-Ghawrī demonstrated his own efforts to be a fair, clement, and godly ruler. We can, therefore, argue that the reading of historical material in the sultan's majālis not only established shared notions of good rule among the members of the court and thus fulfilled an important function in the social construction of a shared reality but also legitimated al-Ghawri's rule, who is depicted as seeking to perfect his own conduct as a ruler through the study of the past.

However, the historical texts that members of the sultan's court studied and commented on both included lessons about the proper behavior of rulers and offered points of reference for the shared outlook of a courtly elite that sought to abide by certain intellectual and ethical standards. Al-'Uqūd al-jawhariyya contains a lengthy historical anecdote about how a woman who belonged to "the daughters of the royal ladies (banät al-khawandāt)" approached the Shāfi'i chief judge, claiming that the Mamluk ruler al-Ẓāhir Barqūq (r. 784-91/1382-9 and 792-801/1390-99) was her slave who had never been freed and was therefore unfit to rule. The judge thereupon summoned Barqūq, and the woman produced evidence of his slave status. When the amir kabir of the time offered to buy Barqūq for 400 dīnārs, the woman declined and stated that she would only sell him to the judge. The judge thereupon sold all his belongings, purchased Barqūq from the woman for 22 dīnārs, and freed him. Barqūq was subsequently

43 Word illegible in the manuscript.

44 Anonymous, al- $U q \bar{u} d \mathrm{i}, 79^{\mathrm{r}-\mathrm{v}}$. I have not been able to pin down the source of this anecdote. 


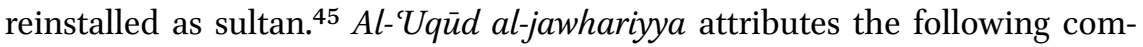
ment on this anecdote to al-Ghawrï: "In this time, the judges had long tongues [i.e., were eloquent] and short hands [i.e., did not seek worldly gain]. Now, they have long hands and short tongues." 46

This episode is not typical for the historical material discussed in al-Ghawri's majālis insofar as it addresses the history of the Mamluk Sultanate, which usually did not figure prominently in these events, at least as far as our sources tell us. This particular anecdote about the purchase of a Mamluk ruler, however, apparently appealed to the members of al-Ghawrî's circle. The unusual idea of a ruler being sold for a comparatively small price surely accounted for a significant share of its attractiveness. However, the members of al-Ghawri's majālis might also have considered the anecdote valuable for the contribution it could make to their shared project of constructing and affirming a common framework of proper behavior. The story championed several key virtues that must have resonated with members of the Mamluk court, including respect for Islamic law as expressed by all of its dramatis personae, financial unselfishness as practiced by the unnamed courtly woman, and respect for rulers as well as the proper exercise of one's office as exemplified by the judge. As alGhawri's final remark made clear, adhering to the high moral standards the anecdote set was considered a challenge. Yet by studying historical material that contained ethical advice such as the story in question, the members of al-Ghawri's circle demonstrated their commitment to a shared vision of how both civilian and military members of the elite of the Mamluk Sultanate should behave.

The comments by members of the sultanic majälis on material about the past examined so far could seem to be rather uncritical. The majälis participants apparently took up the historical information they found in the available literature and integrated it into their efforts to construct a shared social reality. Other comments, however, reveal that the majālis participants did not slavishly accept each and every statement they found in their readings but had agency in appropriating and manipulating the past in accordance with their needs and convictions. This could go so far as to include outright rejection of statements found in works about the past, as the following example from Nafā'is majālis al-sulțāniyya shows: "The author of al-Aqā̉i said: 'Gabriel came 24,0oo times to the Prophet-peace be upon him.' Answer: I [i.e., the firstperson narrator] said: 'This would necessarily mean that Gabriel came down to

45 Anonymous, al- ${ }^{-}$qū $d \mathrm{ii}, 43^{\mathrm{v}}-4^{\mathrm{r}}$.

46 Ibid. $44^{\mathrm{r}}$. 
him - upon whom be peace - three times a day, although the period in which the Prophet received no revelation ( fatrat al-wahy) is clearly established in the authentic traditions.' "47 The work referred to here as al-'Aqā̉i $i q$ was, as I show elsewhere, ${ }^{48}$ Abū Muḥammad 'Abd al-Raḥmān b. Marwān b. al-Munajjim alMa'arri’s (d. 557/1162) Kitābal-'Aqä̉iqfí ishārātal-daqā̉iq, which, although more a parenetic than a historiographical text, served the members of al-Ghawri's majālis as an important source of information on pre- and early Islamic history. Our sources indicate that they read at least considerable portions of the work over an extended period. ${ }^{49}$ Sultan al-Ghawrī, in particular, held the work and its author in high esteem. During a majlis in al-Rabī' I 911/August-September 1505, he recited the first Sura of the Quran three times for the benefit of al-Macarri's soul $^{50}$ — an, as far as we can say, singular gesture of respect toward a long-dead author.

However, it was possible in the sultan's majälis to criticize even a person of al-Ma'arri's standing if his writings were perceived as falling short of the participants' intellectual standards. Using his agency as a reader, the first-person narrator of Nafä̉is majālis al-sulțāniyya pointed out a problematic passage in the work and refuted it, thereby demonstrating his acumen and learning. Arguably, he acted here as a kind of representative of the majālis participants, who through their collective critical reading of works such as al-Ma'arrīs Kitäb al'Aqāi $i q$ performatively demonstrated and enacted their claims to the status of well-lettered $u d a b \bar{a}$.

While the observations that readers had agency over the texts they consumed and that they exercised this agency inter alia through practices of commenting is hardly surprising, the accounts of al-Ghawri's majālis also indicate that works about the past could themselves possess agency by influencing and shaping the course of the debate. A case in point is the famous popular epic Sirat Baybars about the exploits of the early Mamluk ruler al-Malik al-Zāhir Baybars (r. 658-76/126o-77), which in al-Ghawri's time had acquired a sufficiently stable form to be regarded a written work about the Mamluk past. ${ }^{51}$ Yet, when one of the majälis participants brought fascicles of what appears to have

\footnotetext{
47 Al-Sharīf, Nafäìs (MS) 203.

48 See Mauder, Salon, chapter 4.2.4.

49 E.g., al-Sharīf, Nafằis (MS) 73, 141, 145, 191, 203, 207, 210-1, 233, 247-8, 256, 259; (ed. 'Azzām) $77,93,95,131,135$.

50 Al-Sharīf, Nafã̉is (MS) 143; (ed. 'Azzām) 54.

51 Sìrat al-Zāhir Baybars has received considerable attention in recent years. Examples of particularly important publications include Herzog, Geschichte; Legitimität; Garcin (ed.), Lectures (and the contributions therein); Garcin, Histoire (both parts).
} 
been this work ${ }^{52}$ and another text to the citadel in order to read them in a meeting of the sultan's circle on the last day of Ramadān 910/early March 1505, his suggestion met with opposition:

Shaykh Umm Abī l-Hasan came with two books, one of which was the sìra of al-Malik al-Z̄āhir Baybars and his entry into (dukhūluhu ilā) [the lands of] the Franks. The second book [included] prophetic traditions about the merit of [being] Muslim ( $f i$ fadl al-muslim). He wanted to read the complete contents of these books, although it is not possible to read them in an entire month.

I said: It is not fitting to read these books in this night. As for the sira of al-Malik al-Z̄āhir, it is [not fitting] because if al-Malik al-Zāhir were [still] alive, he would wish to listen to the sira of the majlis of our lord the sul$\tan$. As for the second book, it is far from being fitting for the night of the Feast [of Breaking the Fast]. Nay, what is fitting in this noble night is mentioning the merit of [the month of] Ramaḍan and the performance of [its fast], and the merit and the blessing of the feast..$^{53}$

In this passage, the first-person narrator of Nafäis majālis al-sulțāniyya gave three reasons why he considered Sirat Baybars inappropriate reading for the majlis: First, in his view, the text was simply too long to be read during one gathering. Second, Sultan Baybars' accomplishments were of such minor significance compared to those of al-Ghawrī that even Baybars himself would have preferred to hear about the latter. And third, the work did not fit the religious character of a majlis held on the last night of Ramaḍan.

Among these three arguments, the second one is of special interest here. Apparently, the first-person narrator feared the agency of Sirat Baybars as a text that would draw attention away from Sultan al-Ghawrī and his courtly majālis to the exploits of his famous predecessor Baybars, whose military accomplishments against Mongols and Crusaders-especially as narrated rather fancifully in Sirat Baybars - threatened to overshadow all achievements that alGhawrī and his intimates could come up with. Moreover, in this case, it seems that the first-person narrator considered commenting and debating the text as insufficient strategies to tame the distractive potential of Sirat Baybars. The risk was apparently too high that any closer engagement with Sirat Baybars would threaten the success of the majālis participants' common project of

$5^{2}$ On the identification of the work introduced in the source simply as Sirrat al-Zāhir Baybars, see Mauder, Salon, chapter 4.2.5.

53 Al-Sharīf, Nafä̀is (Ms) 16; (ed. 'Azzām) 16. 
legitimating the sultan's rule and reaffirming their status as members of the distinguished elite. If Baybars were the benchmark, none of them, not even alGhawrī, could have hoped to appear as an accomplished figure posterity would remember as one of the great men of the sultanate. Therefore, in an-as far as we know-unique move, Sirat Baybars was banned from al-Ghawrìs majälis. With this step, the members of the court acknowledged that their agency as readers was limited and that the success of their common efforts to present themselves as worthy of elite status could be threatened by a text about the past. We thus see that, in the social context of al-Ghawri's court, written works about bygone times were central to the elite's activities in self-legitimation and the construction of a shared social reality, but they could also, if used without appropriate discretion, undermine these very goals. The majālis participants were apparently keenly aware that certain works about the past were too powerful to be collectively consumed and commented on in a courtly setting.

\section{Producing Texts about the Past}

Given that the members of al-Ghawrì's majälis realized the social impact that writings about the past could have, it would have been almost surprising had they not themselves tried their hand at producing such texts. And indeed, they wrote with al-Kawkab al-durrī, al-Uqüd al-jawhariyya, and Nafäis majālis al-sulțāniyya at least three texts about the-in this case immediate-past, namely, their experiences in the sultan's gatherings. The fact that these works did not belong to the predominant genres of Mamluk historiography (i.e., the chronicle and the biographical dictionary) but were rather produced in the time-honored, but in the Mamluk period rather uncommon, genre of courtly majālis literature that blossomed especially in 'Abbasid and Buyid times, should not mislead us in this regard. ${ }^{54}$ Yet, who wrote these works, and why?

Of the three named texts, we can answer these questions most precisely for Nafäis majālis al-sulțāniyya, which in the following serves as the subject of a case study on writing about the past at the late Mamluk court. Its author, Ḥusayn b. Muhammad al-Ḥusaynī, known as al-Sharīf, does not seem to feature in any other known source. His work, however, provides considerable information about his origin, educational background, and social status in Mamluk Cairo. As both his name and al-Sharīf's explicit statement make clear, he 
claimed to be a descendant of the Prophet Muhammad through the line of the latter's grandson, Ḥusayn b. 'Alī b. Abī Ṭālib (d. 61/68o). ${ }^{55}$ Al-Sharīf was not of local Egyptian background but identified his home region as bilād al-'ajam ${ }^{56}$ (i.e., the land of the non-Arabs). The specific way he uses this term in his text suggests that in this case, it might refer more precisely to the territory of the Turkmen dynasty of the Qarā Qoyunlu (Black Sheep), who ruled over Eastern Anatolia, the eastern part of modern Iraq, and most of Iran. ${ }^{57}$ That al-Sharif appears to describe his home region in reference to this dynasty might implicate that he was born before its subjugation by the Āq Qoyunlu (White Sheep) in the early 870s/late 146 os.

Al-Sharif was multilingual and knew at least Arabic, Persian, and Ottoman Turkish, as his use of these languages in his work indicates. His command of Arabic, however, was far from perfect, as the considerable number of recurring grammatical mistakes throughout his work demonstrates, including its very title, which, according to the rules of Arabic grammar should read Nafäis almajālis al-sulțāniyya fi haqāàiq al-asrār al-Qur'āniyya instead of Nafä̀is majālis al-sulțāniyya fi hạaqūiq asrār al-Qurānniyya ${ }^{58}$ Moreover, al-Sharif seems to have lived a considerable time in a region characterized by Persianate culture, as his frequent references to pre-Islamic Persian personages, Iranian history, and Persianate lore throughout his work suggest. ${ }^{59}$ Furthermore, al-Sharif apparently had a preference for the Hanafi school of law, which he usually mentions first and whose views he gives the most space when narrating legal debates in alGhawrī's majālis. ${ }^{60}$ This preference could be explained either through the legal identity of the Mamluk ruling military that was almost consistently Hanafí or through al-Sharif's assumed area of origin, where this madhhab was the most common. ${ }^{61}$

Even if we cannot establish beyond doubt that al-Sharif was a Hanafî, the religious terminology used and views expressed in his work do show beyond doubt that he was a Sunni. ${ }^{62} \mathrm{He}$ may have left his home region for this very reason, given that his appearance in Cairo coincided with the rise of the Shici

\footnotetext{
55 Al-Sharīf, Nafā’is (MS) 203-4; (ed. 'Azzām) 88.

56 Al-Sharīf, Nafằis (Ms) 221; (ed. 'Azzām) 101.

57 Cf. al-Sharīf, Nafẳis (Ms) 224; (ed. 'Azzām) 105.

58 See Mauder, Salon, chapter 3.1.1.3.

59 See Ibid.; Irwin, Literature 28.

6o Al-Sharīf, Nafã'is (MS) 11, 62, 103, 107, 138, 159, 220, 224; (ed. 'Azzām) 10, 10o, 105-6.

61 Cf. Heffening and Schacht, Hanafiyya 163, on the spread of the Hanafĩ school of law in the eastern part of the Islamicate world.

62 Cf., e.g., al-Sharīf, Nafẳis (MS) 271; (ed. 'Azzām) 149.
} 
Safavids in former Qarā Qoyunlu territories. ${ }^{63}$ In the cultural context of alGhawrī's court, his Persianate background might have been a valuable asset, given that a contemporaneous chronicler noted that the sultan "was inclined toward the Persians (abnä al-'ajam)."64

Whether because of his region of origin or other reasons, al-Sharif managed to become a client of al-Ghawri’s, who in Rabī' I 911/August 1505 gave him a paid position as Sufi in his funeral complex. ${ }^{65}$ However, his relationship with the sultan suffered a severe setback when, over the course of the last three majälis narrated in the work that took place in late Rajab to early Sha'bān 911/December 1505, al-Sharif stubbornly defended his view about a seemingly minor question of Quranic exegesis. His adversaries in this debate included al-Ghawrī, whom al-Sharif implicitly accused of harboring Mu'tazilì tendencies. In reaction, the furious sultan brought the majālis to an abrupt end and banished all of their participants, including al-Sharif, from his presence. ${ }^{66}$ The implications of this outcome of the debate for al-Sharif can hardly be overestimated, given that his economic well-being and social status in Cairo depended on the sultan's goodwill.

We have every reason to assume that this crisis of patronage was the immediate reason for the composition of Nafäis majālis al-sultäniyya, as becomes especially clear in the final passages of the work, which follow al-Sharif's presentation of the last fateful majlis the sultan had so brusquely ended. The first passage of relevance here is introduced as an "apology (itidhär)." There, al-Sharif begs his readers for forgiveness for his mistakes. ${ }^{67}$ While works of the Mamluk period regularly included such passages that formed part of a convention of literary production, the passage is noteworthy because it sets the tone for the following section of the text, which is introduced as șurat al-qișsa or "the form of [my] petition":68

63 Cf. Roemer, Safavid period 212-20.

64 Ibn Iyās, Badā'i v v, 88. See also Ibn al-Ḥanbalī, Durr ii.1, 48-9; Alhamzah, Patronage 38; Flemming, Perser 82; Nachtgesprächen 24. On the patronage received by Persianate immigrants in the Mamluk Sultanate, see also Petry, Elite 61, 67-8; Underworld 26o-2; Patterns, 173-4; Fernandes, Politics 96.

65 Al-Sharīf, Nafä̃is (Ms) 115; (ed. 'Azzām) 36. See also Al-Sharīf, Nafāìs (ms) 205-6; (ed. 'Azzām) 90-1. On al-Ghawri’s funeral complex, see Alhamzah, Patronage.

66 Al-Sharīf, Nafã̉is (MS) 259-65; (ed. 'Azzām) 135-43. For detailed analyses of these debates, see Mauder, Salon, chapters 3.1.1.3 and 4.2.2.

67 Al-Sharīf, Nafāitis (Ms) 268-9; (ed. 'Azzām) 145-6.

68 For the translation of qișșa as "petition" in the Mamluk context, cf., e.g., Sijepesteijn, Troubles 359; Pellat, Kiș̣̦a 186-7. See also al-Qalqashandī, Șubḥ vi, 202. 
Then, I sent a piece of writing (kitāb) through ('alā yad) the lord of the merchants in the world, the generous and liberal one, the most honorable of the servants of God in the presence of the greatest sultan of the lands of God, Khawājā Muhammad b. 'Abbād Allāh-may God increase his excellence and perfection. It [i.e., the piece of writing] included a Quranic verse [and read]:

"I am in any case a sinner

But if you want, forgive us what

God Most High said in his and what the revealed law dictates is obligatory

we've committed, and if you want, punish [us].

noble Book: 'And if You punish them, they are Your servants; if You forgive them, You are the Almighty, the Wise.' [Q 5:118]

The intercessor of the sinners, and the friend of those who are repentant [i.e., Muhammad] said: 'For each thing, there is an expedient (hïla), and the expedient for sins is repentance. 69

Oh sultan of sultans (sultāan al-salāțīn), oh shadow of God on earth, oh you who is clement [even] if you are in wrath, oh noblest of the rulers of non-Arabs and Arabs, forgive me my sin, and condone my shortcoming!"70

What al-Sharif describes here is an earlier attempt to regain the sultan's favor with the help of a third person, who conveyed al-Sharif's written apology to the sultan. ${ }^{71}$ In it, al-Sharif readily acknowledged his guilt and pleaded for al-Ghawri's forgiveness through references to the Islamic religious tradition. However, it seems that this first attempt to reestablish cordial relations with the sultan failed, as the text of Nafäis majälis al-sulțanniyya continues with three poems and a partial citation of the Quranic verse 2:286, which, in Arberry's translation, reads as follows: "Our Lord, take us not to task if we forget, or make

69 This saying is not included in this form in the six canonical books of Sunni hadith.

70 Al-Sharîf, Nafã̃is (Ms) 269-70; (ed. 'Azzām) 146.

71 We do not know much about Khawājā Muhammad b. 'Abbād Allāh except for the fact that he was one of the government officials (mubāshirūn) who were deported to Istanbul after the Ottoman conquest of Egypt, cf. Ibn Iyās, Badāa' ${ }^{\mathrm{c}} \mathrm{v}, 231$. He later returned to Cairo and again became part of the local administration, cf. Ibid. $35^{8}, 403$. He died in or after 927/1521. 
mistake. Our Lord; charge us not with a load such as Thou didst lay upon those before us. Our Lord, do Thou not burden us beyond what we have the strength to bear. And pardon us, and forgive us, and have mercy on us; Thou art our Protector. And help us." The plea for forgiveness as the central topic of this verse reappears in the three poems, the first two of which are in Arabic and the third in Ottoman Turkish. ${ }^{72}$ The second reads:

Oh east wind, blow in the early morning at the gate of the Khusraw, the Lord of Conjunction, ${ }^{73}$

His Excellency, the Sultan, the Commander of the Faithful, ${ }^{74}$ Qānișawh al-Ghawrī, the Beloved of Egypt, the Khān.

His wisdom, his rule and his justice [are like those of] Joseph, Alexander and Anushiruwan. ${ }^{75}$ After kissing the ground, ask much for forgiveness because of the misdeed of the slave with the broken heart. ${ }^{76}$

In light of these verses and the other evidence available, it is obvious that the immediate reason for al-Sharif's writing of Nafä̀is majālis al-sulțāniyya was his need to apologize to the sultan and to regain the latter's patronage. Yet, this insight leads to another question: Why did al-Sharif think that he could reconcile with al-Ghawrì by producing a literary work on the sultan's majālis? What did the ruler-and with him his court-have to gain from the writing of a work that depicted the quite immediate past? ${ }^{77}$

There are several possible answers to these questions, and we can assume that the expected efficacy of the production of Nafäis majālis al-sultāninya as a strategy of patronage (re)acquisition lay inter alia in its polyvalence. First, alSharif could demonstrate through the writing of Nafä̀is majālis al-sulțāniyya that he was an $a d \bar{i} b$ in possession of cultural capital of value to the sultan. To this end, al-Sharif documented in his work his command of the three major Islamicate languages of his time (i.e., Arabic, Persian, and Ottoman Turkish).

72 Al-Sharīf, Nafāìs (MS) 270-2; (ed. 'Azzām) 147-9.

73 On the application of this title to al-Ghawrī, see Mauder, Salon, chapter 6.2.2.

74 On the application of this title to al-Ghawrī, see Ibid. 6.2.3.

75 On the connections between al-Ghawrī, Alexander, and Joseph, see Ibid. 4.2.4 and 6.2.1.

76 Al-Sharīf, Nafă'is (MS) 270; (ed. 'Azzām) 147-8.

77 There is no conclusive evidence of when Nafä̀is majālis al-sulțāniyya was completed, but it must have been produced during al-Ghawrîs lifetime, i.e., no later than ten years after the events depicted therein. Moreover, given what we know about the background of the work, it seems probable that its author completed it in or soon after Sha'bān 911/January 1505 . 
Moreover, he underlined the importance of his role in the sultan's majälis, as becomes apparent from the fact that Nafäis majälis al-sultāniyya credits the first-person narrator with the second-highest number of contributions to the majālis discussions attributed to a specific person. Only al-Ghawrī is depicted as a more active participant in the debates.

Second, through his work, al-Sharif showcased his abilities to support the representation and legitimation of al-Ghawri's rule. The special attention his work paid to al-Ghawrì's contributions to the majälis discussions was wellsuited to presenting the ruler not only as the most important participant in these events but also as a particularly wise and well-cultivated sovereignan adīb-sulțān. Less subtly, Nafäis majālis al-sulțāniyya lauded al-Ghawrī also as a particularly virtuous and powerful ruler who equaled, if not surpassed, the greatest leaders of the past, as al-Sharif's above-quoted apologetic poem makes very clear. Furthermore, al-Sharif's work provided literary accounts of al-Ghawri's practices of consuming and commenting on written works about the past, which, as we saw above, were of representative and legitimating significance.

Third, through his work, al-Sharif documented and contributed to the project of al-Ghawri's court society to establish, affirm, and develop a shared social reality defined by the cultural and behavioral norms of adab. By providing this project with a literary manifestation, al-Sharif not only integrated it into a century-old tradition of Arabic writing about learned gatherings that had seen its heyday in 'Abbasid and Buyid times but also legitimated it as a meaningful undertaking that deserved to be recorded.

Fourth, Nafä̀is majālis al-sulțāniyya was undoubtedly also of commemorative value, as it provided written accounts about the sultan's majälis that its participants, other members of the court, and posterity could access to learn about and remember al-Ghawri's gatherings. ${ }^{78}$ That the members of alGhawri's circle felt the need for such a commemorative text becomes apparent from the above-quoted passage in which the first-person narrator asserts that "if al-Malik al-Ẓāhir were [still] alive, he would wish to listen to the sìra of the majlis of our lord the sultan."79 This self-referential passage illustrated that there was at least a potential demand for a sira or account of al-Ghawri's majālis, which was exactly what al-Sharîf provided in his Nafäis majālis alsultānizya.

78 There is no evidence that Nafä̀is majālis al-sulțäniyya ever circulated beyond courtly readerships during its dedicatee's lifetime.

79 Al-Sharīf, Nafāìs (Ms) 16; (ed. 'Azzām) 16. 
We thus see why al-Sharîf could hope that, by writing Nafäis majālis alsultāniyya, he would regain al-Ghawrì's favor. Whether or not his endeavor was successful, we do not know, as no information about al-Shariff is available in later sources. Nevertheless, his work allows us unique insights into how the social practices of engaging with historiographical works in al-Ghawrī's majālis became themselves part of written texts about the past.

Over the course of the last, troubled years of the Mamluk Sultanate, Sultan Qāniṣawh al-Ghawrī convened regular learned majālis at the Cairo Citadel. During these meetings, the ruler discussed scholarly questions from a broad array of different disciplines with members of his court, many of whom were accomplished members of the scholarly and administrative elite. While history was not the most common topic of debate, it did account for a significant share of the majälis conversations.

The majalis participants engaged with writings about the past in different ways. Consumption of such works in the form of collective reading practices constituted a recurring activity, and there is evidence that various works of history were physically present in the citadel spaces where the majālis took place. The members of the sultan's circle did not consume historiographic literature indiscriminately but rather focused on works that fulfilled certain aesthetic expectations and spoke to their own realities of life. Ibn Khallikān's Wafayāt

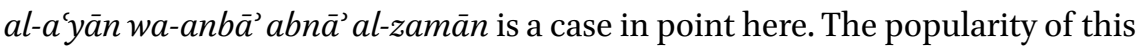
work with the majālis members could be a consequence of both its contents, which reflected the interest of the majälis participants, and its literary qualities, which prompted Hartmut Fähndrich to characterize it as "a biographical dictionary with numerous features that are common to adab-works." 80

In addition to, and as part of, their practices of collective textual consumption, the majālis members discussed and commented on their readings. Our sources attribute to the sultan a particularly active role in these conversations. In particular, they depict al-Ghawrī as evaluating the conduct of the dramatis personae of the historical accounts against a specific body of knowledge and proper behavior our source texts refer to as adab. Moreover, the sources include comments they attribute to other majālis participants, which betray a critical approach to statements in the consumed texts. Apparently, members of the sultan's circle did not hold back their criticism if they considered what they 
read unreliable or even wrong. Yet, the majälis participants' contributions to the body of historical knowledge were not limited to these comments. They also authored at least three texts in which they narrated their experiences in the sultan's gatherings. Rather than constituting minutes taken during the actual meetings, these texts were works about the past written soon, but definitely, after the events they depicted. As our case study of one of these worksal-Sharif's Nafäis majālis al-sulțāniyya-showed, the dynamics of patronage relations could be decisive for the production of these texts, given that the immediate reason for al-Sharîf's writing of Nafä̀is majālis al-sulțāniyya was an earlier quarrel with his patron al-Ghawrī, who had banished al-Shariff from his presence.

Nevertheless, our findings suggest that the majālis participants did not merely read and discuss works about the past to learn about history, nor did alSharîf write Nafä̀is majālis al-sulțāniyya as a simple gift to the sultan. Although each of these practices must be studied individually, they arguably fulfilled similar and, at the same time, multiple social functions. First and foremost, they strongly conveyed the image of al-Ghawrì as a wise and well-lettered sultan who was interested in ethical rulership and sought to situate himself in historic traditions of virtuous rule. While it is thus clear that the various practices of engagement with written works about the past at al-Ghawri's court examined here served to represent and legitimate al-Ghawri's rule, their significance did not end there. The specific choice of texts consumed at court suggests that the sultan and his intimates derived aesthetic pleasure from their readings in addition to acquiring and exchanging cultural capital during their gatherings. Moreover, their collective practices of reading and discussing these texts provided the members of the court with opportunities to showcase their knowledge, acumen, and refinement, thus demonstrating that they were members of a cultured elite of courtly $u d a b \bar{a}$. The norms and values that governed their belonging to this elite group likewise found expression in their perusal and discussion of historical works, which thus contributed to the social construction of a shared reality. Last but not least, the writing of works about the majālis commemorated these events that represented such important functions in the lives of their participants.

These observations have at least two implications for the broader understanding of late Mamluk intellectual history. First, contrary to what has been assumed, especially by scholars of Arabic literature, courts did matter as centers in the consumption and production of texts in Arabic during the Mamluk period. ${ }^{81}$ While this is not to say that communication among people unas-

81 For recent publications doubting the significance of courts in the intellectual and literary 
sociated with courts did not form an important part of Mamluk literary and intellectual life, there can be no doubt that courtly patronage existed in the late Mamluk period and that it had an impact on how people thought and wrote about the past.

Second, learned debates at the late Mamluk court largely took place against a background of a specific body of knowledge and behavioral practices our sources refer to as adab. Closely connected to courtly aesthetics, the concept of $a d a b$ functioned as an overarching frame of reference that members of the Mamluk court used to imagine and construct their own place in the world. As such, it shaped their approach to texts about the past, which were of central importance to their endeavors to legitimate their status. Future research must show whether $a d a b$ also fulfilled similar functions with regard to other fields of knowledge cultivated in the courtly sphere.

\section{Bibliography}

\section{Manuscripts}

Anonymous, al-Kawkab al-durrīfìmasāìl al-Ghawrī, Ms Istanbul, Topkapı Sarayı Kütüphanesi, Ahmet III 1377.

Anonymous, al-Uqūd al-jawhariyya fì l-nawādir al-Ghawriyya, Ms Istanbul, Süleymaniye Kütüphanesi, Ayasofya 3312 and 3313.

al-Sharīf, H.̣., Nafẳis majālis al-sulțāniyya fì haqā̉iq asrār al-Qur'āniyya, Ms Istanbul, Topkapı Sarayı Kütüphanesi, Ahmet III 268 o.

\section{Primary Sources}

'Azzām, 'A. (ed.), Majālis al-Sulțān al-Ghawrī: Șafahāt min tārīkh Mișr min al-qarn alāshir al-hïrī, Cairo 1941.

Ibn al-Ḥanbalī, R., Durr al-habab fì tārīkh a'yān Halab, ed. M.M. al-Fākhūrī and Y. 'Abbāra, 2 vols, Damascus 1972-3.

Ibn Iyās al-Ḥanafī, A., Badā̄i' al-zuhūr fì waqā̄i' al-duhūr [= Die Chronik des Ibn Ijās]: Mujallad 4: Min sanat go6 ilā sanat 921 h. (1501-1515), ed. M. Muștafā, Wiesbaden ${ }^{2} 1960$.

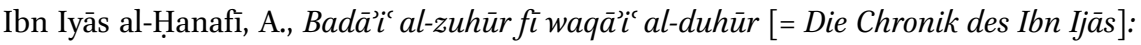
Mujallad 5: Min sanat 922 ilā sanat 928 h. (1516-1522), ed. M. Mușțafā, Wiesbaden ${ }^{2} 1961$.

life of the late middle period, see, e.g., Bauer, Shā'ir 720; Communication 23; Anthologien 83; Herzog, Culture 145; Muhanna, Century 352; Talib, Epigram 89-9o. For a critical reaction to this view, see van Steenbergen, Discourse, esp. 3. 
Ibn Khallikān, A., Wafayātal-ayān wa-anbā’a abnā'al-zamān, ed. I. 'Abbās, 8 vols., Beirut 1968-77.

al-Qalqashandī, A., Șubḥ al-a shā fì șināa at al-inshā’, ed. M.Q. al-Baqlā. 14 vols., Cairo 1913-22, repr. 197 o.

\section{Secondary Sources}

Alhamzah, Kh.A., Late Mamluk patronage: Qansuh al-Ghürìs waqf and his foundation in Cairo, Boca Rato 2009.

Awad, M., Sultan al-Ghawri: His place in literature and learning (three books written under his patronage), in International Congress of Orientalists (ed.), Actes du xxe Congreès International des Orientalistes: Bruxelles 5-10. September 1938, Louvain 1940, 321-2.

Bauer, Th., Adab: c) and Islamic scholarship after the "Sunnī revival," in $E I^{3}$.

Bauer, Th., Shāirir, in $E I^{2}$, xii, 717-22.

Bauer, Th., Literarische Anthologien der Mamlūkenzeit, in St. Conermann and A. Pistor-Hatam (eds.), Die Mamlūken: Studien zu ihrer Geschichte und Kultur; zum Gedenken an Ulrich Haarmann (1942-1999), (Asien und Afrika 7), Schenefeld 2003, 71-122.

Bauer, Th., Mamluk literature as a means of communication, in St. Conermann (ed.), Ubi sumus? Quo vademus? Mamluk studies, state of the art ( $\left.\mathrm{MaS}_{3}\right)$, Göttingen 2013, $23-56$.

Behrens-Abouseif, D., Sultan al-Ghawrī and the arts, in MSR 6 (2002), 71-94.

Behzadi, L., The art of entertainment: Forty nights with Abū Hayyān al-Tawhīì̄, in L. Behzadi and V. Behmardi (eds.), The weaving of words: Approaches to classical Arabic prose, Würzburg 2009, 165-79.

Berger, L., Aphorism, in $E I^{3}$.

Berger, P., and Th. Luckmann, The social construction of reality: A treatise in the sociology of knowledge, Garden City 1966.

Berkey, J.P., The Mamluks as Muslims: The military elite and the construction of Islam in medieval Egypt, in Th. Philipp and U. Haarmann (eds.), The Mamluks in Egyptian politics and society, Cambridge 1998, 163-73.

Bonebakker, S.A., Adab and the concept of belles-lettres, in J. Ashtiany (ed.), Abbasid belles-lettres (The Cambridge History of Arabic Literature 2), Cambridge 1990, 16-30.

Conermann, St., Es boomt! Die Mamlūkenforschung (1992-2002), in St. Conermann and A. Pistor-Hatam (eds.), Die Mamlüken: Studien zu ihrer Geschichte und Kultur; zum Gedenken an Ulrich Haarmann (1942-1999) (Asien und Afrika 7), Schenefeld 2003, 1-69.

Elbendary, A., Crowds and sultans: Urban protest in late medieval Egypt and Syria, Cairo 2015.

Enderwitz, S., Adab: b) and Islamic scholarship in the 'Abbāsid period, in $E I^{3}$. 
Fähndrich, H., Man and men in Ibn Khallikān: A literary approach to the Wafayāt alA'yān, PhD diss., University of California 1972.

Fähndrich, H., The Wafayāt al-Ayān of Ibn Khallikān: A new approach, in JAOs 93-4 (1973), 432-45.

Fähndrich, H., Der Begriff "adab" und sein literarischer Niederschlag, in W. Heinrichs (ed.), Orientalisches Mittelalter (Neues Handbuch der Literaturwissenschaft 5), Wiesbaden 1990, 326-45.

Fernandes, L., Mamluk politics and education: The evidence from two 14th century waqfiyya, in $A I 23$ (1987), 87-98.

Flemming, B., Šerīf, Sultan Ġavrī und die "Perser”, in Der Islam 45 (1969), 81-93.

Flemming, B., Aus den Nachtgesprächen Sultan Gaurīs, in H. Franke, W. Heissig and W. Treue (eds.), Folia rara: Wolfgang Voigt LXV. diem natalem celebranti ab amicis et catalogorum codicum orientalium conscribendorum collegis dedicata, Wiesbaden 1976, 22-8.

Flemming, B., Literary activities in Mamluk halls and barracks, in M. Rosen-Ayalon (ed.), Studies in memory of Gaston Wiet, Jerusalem 1977, 249-6o.

Frenkel, Y., Is there a Mamlūk culture? (U HML 8), Schenefeld 2014.

Frenkel, Y., The Mamluks among the nations: A medieval sultanate in its global context, in St. Conermann (ed.), Everything is on the move: The Mamluk empire as a node in (trans-)regional networks ( $\mathrm{MaS}_{7}$ ), Göttingen 2014, 61-79.

Gabrieli, F., Adab, in $E I^{2}$, i, 175-6.

Garcin, J.-C. (ed.), Lectures du roman de Baybars, Marseille 2003.

Garcin, J.-C., Sīra/s et histoire [Part 1], in Arabica 51 (2004), 33-54.

Garcin, J.-C., Sïra/s et histoire [Part 2], in Arabica 51 (2004), 223-57.

Hämeen-Anttila, J., Adab: a) Arabic, early developments, in $E I^{3}$.

Heffening, W., and J. Schacht, Hanafiyya, in $E I^{2}$, iii, 162-4.

Herzog, Th., Legitimität durch Erzählung: Ayyūbidische und kalifale Legitimation mamlūkischer Herrschaft in der populären Sirrat Baybars, in St. Conermann and A. Pistor-Hatam (eds.), Die Mamlūken: Studien zu ihrer Geschichte und Kultur; zum Gedenken an Ulrich Haarmann (1942-1999) (Asien und Afrika 7), Schenefeld 2003, 251-68.

Herzog, Th., Geschichte und Imaginaire: Entstehung, Überlieferung und Bedeutung der Sirat Baibars in ihrem sozio-politischen Kontext (DA 8), Wiesbaden 2006.

Herzog, Th., Mamluk (popular) culture: The state of research, in St. Conermann (ed.), Ubi sumus? Quo vademus? Mamluk studies, state of the art ( $\left.\mathrm{MaS}_{3}\right)$, Göttingen 2013, $131-58$.

Irwin, R., Mamluk literature, in MSR 7 (2003), 1-29.

Irwin, R., The political thinking of the "virtuous ruler," Qansuh al-Ghawri, in MSR 12 (2008), 37-49.

Lapidus, I.M., Knowledge, virtue, and action: The classical Muslim conception of adab 
and the nature of religious fulfillment in Islam, B.D. Metcalf (ed.), Moral conduct and authority: The place of adab in South Asian Islam, Berkeley 1984, 38-61.

Lichtenstädter, I., On the conception of $a d a b$, in $M W 33$ (1943), 33-8.

Mauder, Ch., Herrschaftsbegründung durch Handlung: 'Abd al-Bāsiṭ al-Malațīs (st. 1514 in Kairo), al-Mağmū'al-bustān an-nawrī (Die erblühende Gartensammlung), in Das Mittelalter 20 (2015), 29-46.

Mauder, Ch., In the sultan's salon: Learning, religion and rulership at the Mamluk court of Qāniṣawh al-Ghawrī (r. 1501-1516), PhD diss., University of Göttingen 2017.

Mauder, Ch., and Ch.A. Markiewicz, A new source on the social gatherings (majālis) of the Mamluk sultan Qānșawh al-Ghawrī, in Al-'Usur al-Wusta 24 (2016), 145-8.

Muhanna, E., Why was the 14th century a century of Arabic encyclopaedism?, in J. König and G. Woolf (eds.), Encyclopaedism from antiquity to the renaissance, Cambridge $2013,343-56$.

Nallino, C.A., La littérature arabe:Des origines à l'époque de la dynastie umayyade (Islam d' hier et d' aujourd' hui 6), trans. Ch. Pellat, Paris $195^{\circ}$.

Pauliny, J., Die Anekdote im Werke Ibn Hallikāns, in Asian and African Studies 3 (1967), 141-56.

Pellat, Ch., Kiș̣̦a, in $E I^{2}$, v, 185-7.

Pellat, Ch., Adab in Arabic literature, in EIr, i, 439-44.

Petry, C.F., The civilian elite of Cairo in the later middle ages (Princeton Studies on the Near East), Princeton 1981.

Petry, C.F., A paradox of patronage during the later Mamluk period, in $M W 73$ (1983), 182-207.

Petry, C.F., Twilight of majesty: The reigns of the Mamlūk Sultans al-Ashrāf Qāytbāy and Qanșūh al-Ghawrī in Egypt (Occasional Papers of the Middle East Center, Jackson School of International Studies 4), Seattle 1993.

Petry, C.F., Protectors or praetorians? The last Mamlük sultans and Egypt's waning as a great power (s UnY Series in Medieval Middle East History), Albany 1994.

Petry, C.F., The military institution and innovation in the Mamlūk period, in C.F. Petry (ed.), The Cambridge history of Egypt, i, Cambridge 1998, 462-89.

Petry, C.F., The criminal underworld in a medieval Islamic society: Narratives from Cairo and Damascus under the Mamluks (Chicago Studies on the Middle East 9), Chicago 2012.

Petry, C.F., "Travel patterns of medieval notables in the Near East" reconsidered: Contrasting trajectories, interconnected networks, in S. Conermann (ed.), Everything is on the move: The Mamluk empire as a node in (trans-)regional networks ( $\mathrm{MaS} 7$ ), Göttingen 2014, 165-79.

al-Qadi, W., Biographical dictionaries as the scholars' alternative history of the Muslim community, in G. Endreß (ed.), Organizing knowledge: Encyclopaedic activities in the pre-eighteenth century Islamic world (IPTS 61), Leiden 2006, 23-76. 
Roemer, H.R., The Safavid period, in P. Jackson and L. Lockhart (eds.), The Timurid and Safavid periods (The Cambridge History of Iran 6), Cambridge 1986, 189-350.

Sijepesteijn, P.M., Financial troubles: A Mamluk petition, in A.E. Franklin (ed.), Jews, Christians and Muslims in medieval and early modern times: A Festschrift in honor of Mark R. Cohen (Christians and Jews in Muslim Societies 2), Leiden 2014, 352-66.

Talib, A., How do you say "epigram" in Arabic? Literary history at the limits of comparison (Brill Studies in Middle Eastern Literatures 40), Leiden 2018.

Van Steenbergen, J., Qalāwūnid discourse, elite communication and the Mamluk cultural matrix: Interpreting a 14th-century panegyric, in JAL 43 (2012), 1-28.

Wedeen, L., Peripheral visions: Publics, power, and performance in Yemen, Chicago 2008. 